\title{
Predispersal home range shift of an ocelot Leopardus pardalis (Carnivora: Felidae) on Barro Colorado Island, Panama
}

\author{
Rafael Mares ${ }^{1}$, Ricardo S. Moreno ${ }^{2}$, Roland W. Kays ${ }^{3}$ \& Martin Wikelski ${ }^{4,5}$ \\ 1. Department of Zoology, University of Cambridge, Downing Street, Cambridge CB2 3EJ, UK; crm53@cam.ac.uk \\ 2. Smithsonian Tropical Research Institute, Box 2072, Balboa, Ancon, Panama; MorenoRS@si.edu \\ 3. New York State Museum, 3140 CEC, Albany, NY 12230, USA; rkays@mail.nysed.gov \\ 4. Princeton University, Department of Ecology and Evolutionary Biology, Eno Hall 211, Princeton, NJ 08544, USA; \\ wikelski@princeton.edu \\ 5. Max Planck Institute for Ornithology, Dept. of Migration and Immunoecology, Schlossallee 2, D-78315 Radolfzell, \\ Germany.
}

Received 05-III-2007. Corrected 25-X-2007. Accepted 05-V-2008.

\begin{abstract}
Home range shifts prior to natal dispersal have been rarely documented, yet the events that lead a subadult to abandon a portion of its home range and venture into unfamiliar territories, before eventually setting off to look for a site to reproduce, are probably related to the causes of dispersal itself. Here, we used a combination of manual radio-tracking and an Automated Radio Telemetry System to continuously study the movements of a subadult male ocelot (Leopardus pardalis), a solitary carnivore with sex-biased dispersal, on Barro Colorado Island, Panama, for 18 months from May 2003 through October 2004. The subadult ocelot's parents were also radio-tracked to record possible parent-offspring interactions within their home ranges. At the age of ca. 21 months the subadult gradually began to shift its natal home range, establishing a new one used until the end of the study, in an area that had previously been used by another dispersing subadult male. Only three parent-offspring interactions were recorded during the four months around the time the range-shift occurred. The apparent peaceful nature of these encounters, along with the slow transition out of a portion of his natal home range, suggest the subadult was not evicted from his natal area by his parents. The timing of the shift, along with the subadult's increase in weight into the weight range of adult ocelots four months after establishing the new territory, suggests that predispersal home range shifts could act as a low risk and opportunistic strategy for reaching adult size, while minimizing competition with parents and siblings, in preparation for an eventual dispersal into a new breeding territory. Rev. Biol. Trop. 56 (2): 779-787. Epub 2008 June 30.
\end{abstract}

Key words: predispersal, subadult, ocelot, Leopardus pardalis, home range shift, automated radio telemetry.

Dispersal, the process by which individuals abandon the immediate environment of their parents to find a site to reproduce, is a major determinant of gene flow, population spread, and the colonization of new areas (Bowler and Benton 2005). Although it is a process of great importance in ecology, animal movement is difficult to study (Holden 2006), particularly when individuals leave their home range, and thus dispersal processes are often little understood (Fairbairn 1978, Sutherland et al. 2000, Bowler and Benton 2005).
In mammals, dispersal typically begins when individuals reach a subadult age, and is usually male biased (Greenwood 1980). Several hypotheses have been proposed to explain the ultimate causes of dispersal, including avoidance of inbreeding, competition for resources and competition for mates (Greenwood 1980, Ferreras et al. 2004). Expulsion of juveniles by parents and weakening of social ties are often considered possible proximate causes associated with dispersal, but empirical evidence for this assertion is 
scant (Macdonald and Kays 2005). Possible changes in movement patterns, interactions between conspecifics and physical changes prior to dispersal may play critical roles in determining when and how individuals decide to disperse. Predispersal home range shifts, which refer to the establishment of a temporary home range by an individual before its dispersal, have been rarely documented, yet may be fundamental in understanding dispersal itself.

The ocelot (Leopardus pardalis Linnaeus, 1758) is a solitary carnivore with a social system based around intrasexually exclusive home ranges (Sunquist and Sunquist 2002), and with male biased dispersal (Ludlow and Sunquist 1987, Emmons 1988, Laack 1991, Crawshaw 1995). One study has documented the occurrence of predispersal home range shifts involving subadult male ocelots (Laack 1991). However, the details of these events are not well known, because individuals need to be observed continuously over long periods of time leading up to the final dispersal event. In the current study, we use a combination of manual and automated radio-tracking to describe, in detail, the predispersal home range shift of a subadult male ocelot. Although we cannot generalize widely from a sample size of one, the details recorded here are new, and contribute to the understanding of the processes leading up to dispersal.

\section{MATERIALS AND METHODS}

Study site: we studied ocelots on Barro Colorado Island (BCI), Panama $\left(9^{\circ} 10^{\prime} \mathrm{N}\right.$, $\left.79^{\circ} 51^{\prime} \mathrm{W}\right)$. BCI covers an area of $15.6 \mathrm{~km}^{2}$ and is part of the larger Barro Colorado Nature Monument (BCNM, $54 \mathrm{~km}^{2}$ total), a highly protected study reserve adjacent to the 193.4 $\mathrm{km}^{2}$ Soberania National Park. The minimum distance between the island and the mainland is $200 \mathrm{~m}$, with small islands breaking up this gap in some places (Wright et al. 1994). BCI has an average temperature of $27{ }^{\circ} \mathrm{C}$ and an average annual precipitation of $2600 \mathrm{~mm}$, with $90 \%$ of the rainfall occurring from May through
November (Dietrich et al. 1997). The vegetation of the island is of a tropical moist forest (Holdrige 1967, Croat 1978). BCI's topography is dominated by hills that reach a maximum elevation of $165 \mathrm{~m}$ above sea level.

Estimates of resident ocelots on BCI using live-trapping, radio-tracking and camera trapping data collected prior to and during this study, suggest that at least 15 adult ocelots were present per year on BCI (J. Willis, unpublished). Furthermore, in addition to the ocelots focused on in this study, six ocelots (four females, two males) with radio-collars, and known home ranges, were present on BCI during the time of this study (Moreno et al., unpubl.).

Capture: we captured ocelots with wire box traps (Tomahawk Live Traps) baited with chickens (Mares 2005). We sedated ocelots with ketamine and xylazine (Kreeger 1999), fitted them with a radio-collar (Advanced Telemetry Systems), and estimated their age based on morphological development and dental wear (Tewes 1986, Ludlow and Sunquist 1987, Crawshaw 1995). For the current study we focused on three collared animals: an adult female (MOM), her subadult son (SON) and the large male of that part of the island (MAL) (Kays 2006) that is likely the father of SON. A series of recaptures of SON to make proper adjustments to the size of his radio-collar allowed us to monitor changes in his weight over time, and estimate overall growth rate in size.

We established the relationships between parents and offspring based on home range overlap (Emmons 1988, Laack 1991), and in the case of the mother, further evidence supporting the relationship was provided by a video using an automatic, infrared camera placed at a kill site in February 2003 (AliagaRossel et al. 2006). In this video MOM brings a younger female cub (ca. five months) to a kill site, while both are closely followed by SON (ca. 10 months old at the time).

Data collection: for this study, we used a combination of telemetry locations collected by hand, telemetry bearings collected by one 
automated receiver and telemetry locations triangulated from bearings collected by three automated receivers. Manual telemetry locations of SON were obtained by radio tracking (Kenward 2001) on foot twice a week from May to December 2003, and again between April and October 2004, during day and night. We estimated $95 \%$ and $100 \%$ minimum convex polygons (MCP) with the program Biotas (Ecological Software Solutions), with an independence interval of three hours (Doncaster and Macdonald 1997). We used the 95\% MCP for home range estimates, and present the $100 \%$ MCP for comparative purposes with other studies.

We also monitored the ocelots using an Automated Radio Telemetry System (ARTS) (Kays et al., submitted, see also online www. princeton.edu/ $\sim$ wikelski/research/index.htm). The ARTS uses automated receivers (Sparrow Systems) to scan radio signal strengths of six stationary antennae mounted on an abovecanopy tower, and determine bearings to radiocollared animals (Cochran and Lord 1963, Larkin et al. 1996). We recorded a bearing to each animal every minute. If bearings are available from two or three different towers, animal locations can be bi- or triangulated, respectively, while single-tower bearings can only be used to determine the general direction of an animal.

Because this study was conducted during the construction of the ARTS, not all towers were fully functional for obtaining automated locations across our study site. However, one of the ARTS towers was virtually on the edge of the natal territory of a dispersing (or predispersing) subadult male ocelot. Four of the six stationary antennas received SON's radiocollar signal when he was in his natal home range, and the other two antennas covered areas where he shifted his territory to. The alignment of antenna were not perfect for this purpose, but gave $100 \%$ coverage of SON's natal home range and poorer coverage of his post-shift range. This allowed us to document the movement of the ocelot between his natal home range and new territories with great temporal precision (every minute), based solely on the direction of the signal recorded by the automated receiver.

In order to show the overall pattern of natal home range use, we combined monthly averages of the high-resolution estimate obtained with the ARTS, with monthly averages calculated from manual telemetry before and after these ARTS data were available, totaling 18 months of area use observations. Furthermore, by breaking down the ARTS data into diurnal (6:00-17:59 h) and nocturnal (18:00-5:59 h) observations based on SON's activity pattern (Mares 2005), we were able to determine differences in the proportion of time spent by $\mathrm{SON}$ in his natal home range between the day and night.

When ARTS bearings were available from three adjacent towers between December 2003 and March 2004, they were used to triangulate locations with custom software (IC Telemetry by I. Couzin, Princeton University, USA). The mean error estimated for all ARTS locations in this area was $50.7 \pm 41.0 \mathrm{~m}$ (standard deviation) (Kays et al., submitted). The range over which these three towers could determine locations of the type of collars worn by the ocelots included all of SON's natal territory and enough of the surrounding area to allow us to confidently determine MOM's home range. Because the ARTS collects data on multiple animals with high temporal resolution, it is also a good tool for documenting interactions between radiocollared animals. During this four month period, we also scanned for possible interactions between SON and his parents using simultaneous locations of the pair being studied (SON/ MOM; SON/MAL), no more than $50 \mathrm{~m}$ apart from one another.

\section{RESULTS}

Captures: SON was first captured in May 2003, at the estimated age of 12-14 months, and was subsequently captured and weighed three more times (Fig. 1). The probable mother of this young male, MOM, was captured and radio-collared in January 2004. The dominant 


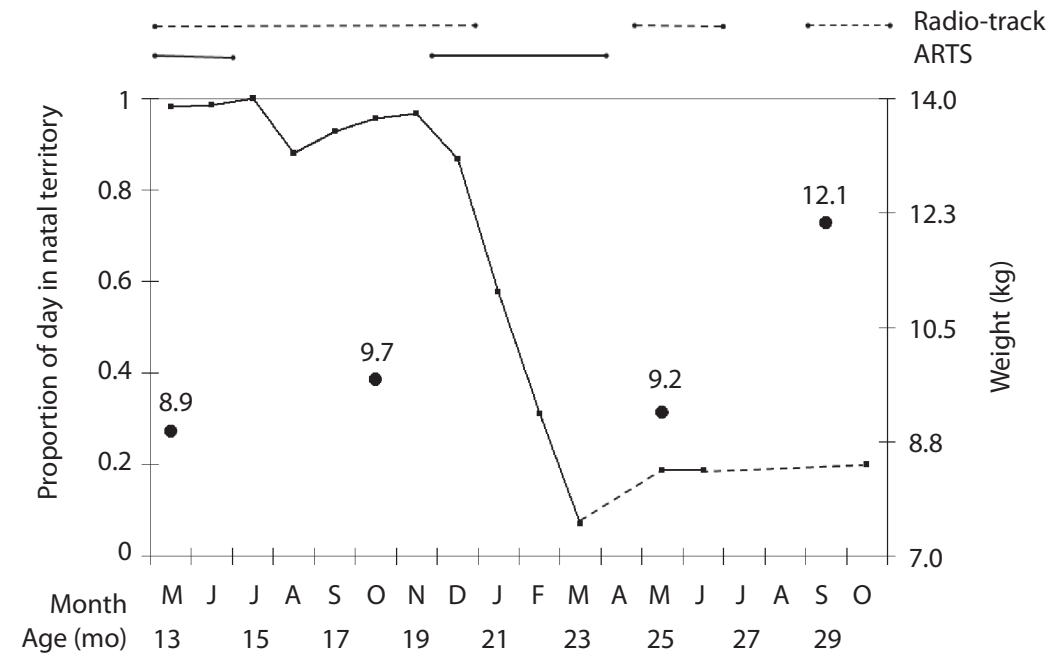

Fig. 1. Transition out of natal home range by a subadult male ocelot (SON) as measured by manual and automated radiotracking (noted above graph). The data range is from May 2003 through October 2004. Weights are body mass measured at captures. Both ARTS and manual data are monthly averages. Averages were not estimated for April and July-September 2004 due to radio-collar failure.

male of the area, MAL, was captured and radio-collared more than a year earlier, in July 2002, thus allowing us to obtain an estimate of his home range before radio-collaring the other two ocelots.

Natal home range estimation: we obtained 238 locations for SON during eight months of radio-tracking (May-Dec 2003), and determined $0.57 \mathrm{~km}^{2} 95 \%$ and $1.14 \mathrm{~km}^{2} 100 \%$ MCPs for his natal home range (Fig. 2). We also determined MOM's home range, using 216 locations obtained with the ARTS during three months (Jan-Mar 2004) for estimating 1.42 $\mathrm{km}^{2} 95 \%$ and $1.87 \mathrm{~km}^{2} 100 \%$ MCPs. MAL's home range was estimated at $6.35 \mathrm{~km}^{2}(9.24$ $\mathrm{km}^{2}$ at $100 \%$ ), using 161 locations obtained during 15 months of manual radio-tracking (Nov 2002-Jan 2004), and it encompasses both SON and MOM's home ranges (Fig. 2). We also estimated that $73 \%$ of SON's natal home range was within MOM's home range.

We identified two main sites within SON's natal home range which he used as resting spots. SON was found several times during the day resting in tangled tree falls within these sites, and one of them was also frequently used by MOM and MAL (site \#1, Fig. 2).

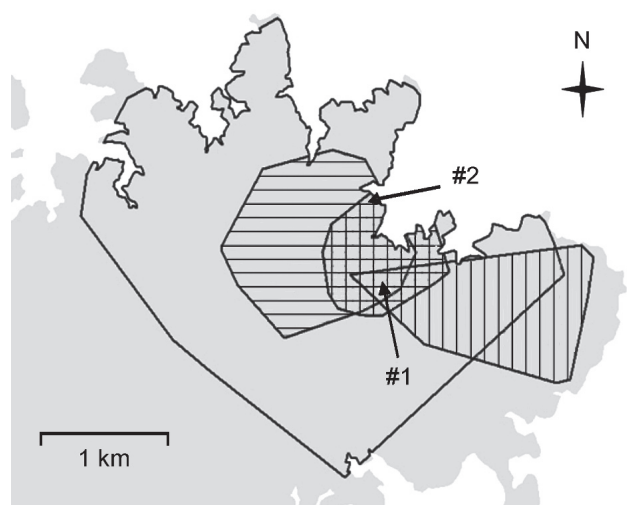

Fig. 2. Home ranges (95\% MCP) of three ocelots including the dominant male of the area (MAL, plain), the presumed mother of the subadult male (MOM, horizontal lines), and the natal home range (grid) and home range shift (vertical lines) of the subadult male (SON). Main resting sites within SON's natal home range are marked \#1 and \#2. Grey shading indicates the outline of Barro Colorado Island. 


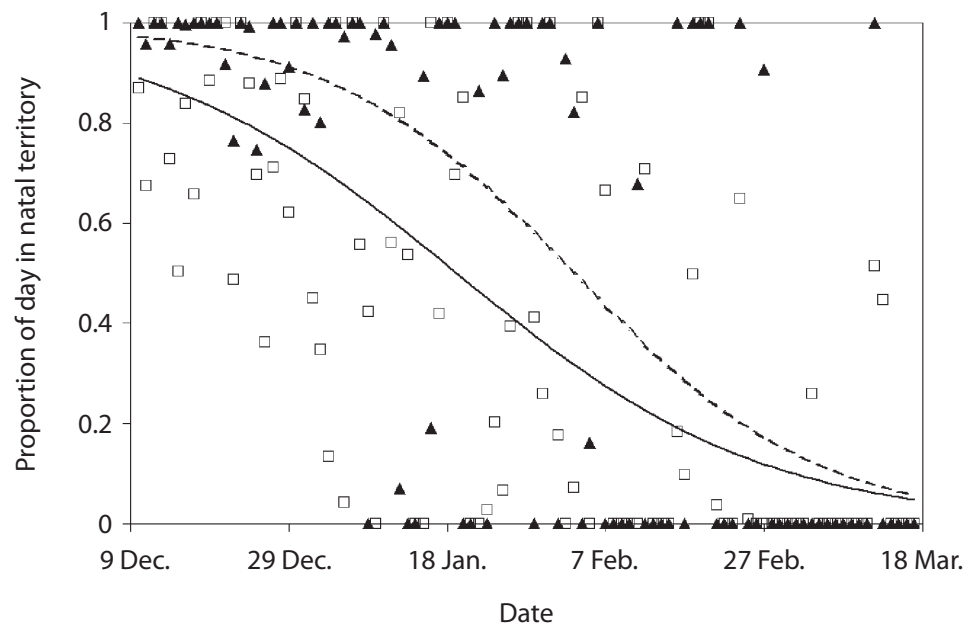

Fig. 3. Transition out of natal home range and difference in time spent in natal home range between day (triangles) and night (squares) as measured by the ARTS for SON over a 4 month period (Dec 2003-Mar 2004). Logistic curve fits are shown for day (dashed) and night (solid) observations.

Predispersal home range shift: monthly averages of the time spent per day by SON in his natal home range, estimated using continuous data obtained with the ARTS and the data from manual tracking locations, show a consistent decrease in the use of the natal area from December 2003 through March 2004 (Fig. 1). When broken down into day and night observations, we determined a difference in the proportion of time spent in the natal area per $12 \mathrm{~h}$ period between the two sets of data over the course of the four months in which the shift took place (Fig. 3).

Between April and October 2004, 41 locations for SON were obtained with manual telemetry to determine the new area used by the subadult, after the home range shift. This $1.24 \mathrm{~km}^{2}\left(1.38 \mathrm{~km}^{2}\right.$ at $\left.100 \%\right)$ territory includes $25 \%$ of his natal home range and also includes resting site \#1. Although this new area still partly overlaps with both MOM's and MAL's home ranges $(5 \%$ overlap with MOM's home range, and $63 \%$ with MAL's), absolute overlap is much less than that observed between these territories and SON's natal home range (Fig. 2). SON's new area also overlaps with the home range of another radio-collared adult female, and is part of a territory that had been used by a subadult male until mid-October 2003, when a combination of dispersal and radio-collar failure prevented us from continuing to monitor this individual (Moreno et al., unpubl.).

We did not continue to actively radio-track MOM, but the fact that she was located several times in the area of resting site \#1 during this period suggests her use of the area had not changed. Sporadic radio-tracking and locations of MAL obtained during this time also suggest there had not been any significant changes in his home range use.

Parents-offspring interactions: A total of three interactions were recorded between December and March 2004. The first involved SON and MOM between 21:00-21:30 $\mathrm{h}$ on February 4 within SON's natal home range. After appearing to stay close together for approximately $30 \mathrm{~min}$, SON traveled in the opposite direction of his initial path and MOM stayed in the same general area (Fig. 4). A second encounter was registered between 11:00-13:00 h on February 26 in the area identified as resting site \#1. 


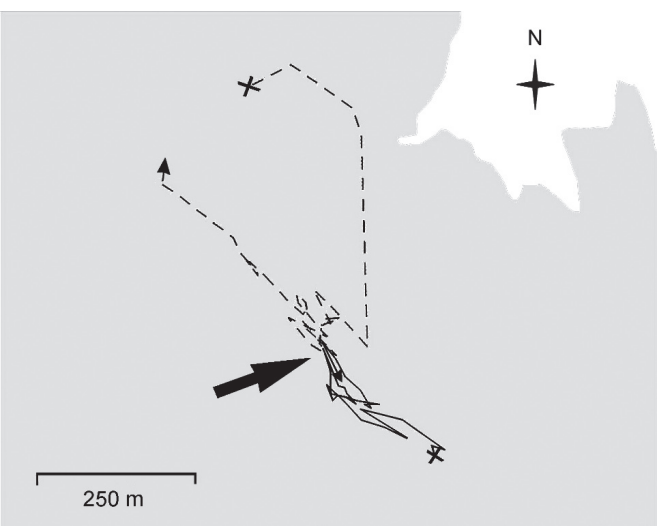

Fig. 4. An interaction between SON (dashed) and MOM (solid) as registered by the ARTS. X indicate the beginning of their movements and small arrows, the end. The large arrow points to the area where they stayed together for approximately $30 \mathrm{~min}$. Accuracy of the locations is estimated at $50 \mathrm{~m}$. Grey shading indicates the outline of Barro Colorado Island.

An interaction between SON and MAL was recorded, and followed from a distance while radio-tracking, on December 30 between 0:00-7:00 $\mathrm{h}$ in the area identified as resting site \#1. Examination of this area the following day revealed the fresh remains of an adult coati (Nasua narica). Only the skull and several hairs were found very close to a spot where the leaves had been removed in a manner that suggested that one of the ocelots had been laying there.

Besides the three encounters recorded by the ARTS, only two others were documented while radio-tracking in the months before and after the home range shift. SON and MAL where located together between 21:00-0:00 h on June 19, 2003. A brief encounter between SON and MOM occurred around 20:15 h on May 7, 2004, in which MOM quickly crossed paths with SON who remained in the area and was heard 45 min later trying unsuccessfully to capture an agouti (Dasyprocta punctata). Furthermore, there were no encounters documented between SON and the other six radiocollared ocelots, including the adult female whose home range overlapped with SON's new area and who was known to use resting site
$\# 1$, despite regular checks for all radio-collar frequencies while radio-tracking SON.

\section{DISCUSSION}

Predispersal home range shift: the pattern of SON's natal home range use began to change in December 2003, when he first left his natal range at the age of 20-22 months, to spend about a third of his time in new areas not visited by MOM (but overlapping with MAL). This is approximately the same age at which three male subadults from Laack's (1991) study began their predispersal home range shifts. SON's home range shift from the natal territory was not a single event, but a gradual process spread over three months that began with journeys outside of his territory, which steadily increased in frequency and duration, and ended four months later with the establishment of a new, stable home range that still included a part of his natal and both parents' home ranges. Differences in natal area use between day and night in the first few months of the home range shift, combined with the predominantly nocturnal activity pattern observed, indicate that initial journeys were mainly nocturnal and ended with the subadult returning to familiar resting sites, similar to what has been observed in dispersing badgers (Meles meles) (Roper et al. 2003).

Captures of SON just before and after his home range shift, show that he lost ca. $5 \%$ of his body weight during this period. A weight loss is consistent with the hypothesis that there may be a cost involved in moving to a new area, presumably associated with the difficulty of hunting in unfamiliar territories (Laack 1991). However, after four months of living in this new area, SON appeared to have adapted to being an efficient hunter as he gained 2.9 $\mathrm{kg}$, reaching the typical weight of adult male ocelots on BCI (Moreno et al., unpubl.). We suspect that spreading the move out over three months reduces potential foraging costs by allowing dispersing males to return to the natal territory to hunt in familiar areas, and possibly even share food with parents. 
Prior to the home range shift, SON had remained in his natal territory for approximately 15 months after the birth of a new female cub by his presumed mother. Similar to our study, Laack (1991) also observed siblings of different litters maintaining ranges that partially overlapped for several months, before the oldest eventually dispersed. Siblings of different litters remaining in the mother's home range show that the dispersal of an individual is not associated with the birth of another litter. This lack of immediate dispersal of older litter mates is similar to what has been observed in lynx (Lynx pardinus) (Ferreras et al. 2004), but different to most other solitary cats, where dispersal is synched with the rearing of a new litter (Smith 1993, Maehr et al. 2002).

SON's predispersal home range shift may be related to the dispersal a month earlier of the subadult male whose territory was adjacent to SON's natal home range (Moreno et $a l$. , unpubl.), and in the area he later went on to occupy. Although radio-collar failure prevented us from being certain that this individual completely abandoned his home range after an initial dispersal event, it is most likely that the area which SON moved into would have been less frequently used, even if only because of an expansion of the dispersing subadult's home range.

Parents-offspring interactions: our automated data on the locations of SON and his parents during this shift period revealed surprisingly few interactions. In our constant monitoring through approximately $5 \mathrm{~km}^{2}$ we found only five interactions between SON and MOM (his probable mother) and MAL (the dominant male of the area and probably his father). Our data, combined with the lack of interactions observed while manually radiotracking, suggest a very low level of contact between subadults and their parents, contrary to what Emmons (1988) found in Peru. Telemetry data cannot characterize the exact nature of interactions between individual ocelots, but the relatively long duration of these interactions and their association with a known diurnal resting spot suggests they were not aggressive. Emmons (1988) also found no evidence of hostility in the 12 interactions documented between subadult male and parent ocelots in Peru. The presence of a fresh kill at the site of the interaction between SON and MAL also suggests the possibility of food sharing, although we do not know if SON was actually allowed to feed.

\section{CONCLUSIONS}

Predispersal home range shifts appear to be relatively common for ocelots (found in three out of five subadult males in Texas, Laack 1991), yet their purpose and causes remain unclear. This study's combination of intensive manual and automated radio-tracking of a subadult male ocelot revealed details about the timing and interactions associated with a predispersal home range shift, that help us understand its potential causes and its direct link to dispersal itself. Although our study ended before an actual dispersal event, it is most likely that at the age of 29-31 months, our subadult ocelot was close to dispersal, considering that all subadult males from previous studies dispersed between the ages of 14-35 months (Ludlow and Sunquist 1987, Emmons 1988, Laack 1991, Crawshaw 1995), including the ones with predispersal home range shifts in Laack's (1991) study, which eventually dispersed between the ages of 30 and 35 months.

The subadult male's weight changes over the course of the home range shift, along with the timing of the shift, suggest that gradually shifting to a nearby range with potentially reduced resource competition, may have allowed him to reach the size of typical adult males (despite the initial costs of exploring new areas), before making a long-distance dispersal. In this sense, predispersal home range shifts could act as a low risk and opportunistic strategy used by subadult males for reaching adult size, while minimizing competition with parents and siblings, in preparation for an eventual dispersal into a new breeding territory. 
As a single data point, our results necessarily have to be interpreted carefully, but we suggest they could be representative of subadult males in areas with limited dispersal opportunities due to saturated habitat (e.g. BCNM and other sites with low levels of poaching) or natural or artificial barriers (roads or human activities as in Texas, Haines et al. 2005). Although separated from the mainland, it is likely that the ocelots on BCI are able to cross the $\sim 200 \mathrm{~m}$ gap, even if only rarely (at least 1 of 14 radio-collared ocelots swam off BCI to the mainland, Moreno et al., unpubl.). Future studies may concentrate more strongly and with larger sample sizes on the ontogeny of movement and space use decisions in ocelots and other long-lived animals.

\section{ACKNOWLEDGMENTS}

We especially thank the Smithsonian Tropical Research Institute (STRI) for their financial and logistic support of the project. This project was also funded by the Peninsula Foundation, the National Geographic Society, the National Science Foundation and the Frank Levinson Family Foundation. Many thanks to, in no particular order, M. Klink, F. Kümmeth, P. Flores, I. Couzin, J. Mandel, D. Obando, K. Sallee, and C. Fiorello for providing technical assistance and making it all work. The research presented here followed STRI's Institutional Animal Care and Use Committee (IACUC) guidelines and was permitted under Princeton University's IACUC protocol \#1440.

\section{RESUMEN}

Los desplazamientos del ámbito hogareño de mamíferos subadultos previos a la dispersión natal rara vez han sido documentados. Sin embargo, los eventos que llevan a un animal subadulto a abandonar una parte de su ámbito natal, antes de buscar un sitio definitivo donde reproducirse, pueden estar relacionados con las causas de la dispersión en si. En este estudio, utilizamos una combinación de radio-telemetría manual y un Sistema de RadioTelemetría Automatizado para estudiar de manera continua los movimientos de un ocelote (Leopardus pardalis) macho subadulto, un carnívoro solitario con dispersión sesgada sexualmente, en la Isla de Barro Colorado, Panamá, durante 18 meses (mayo 2003 hasta octubre 2004). Los padres del ocelote subadulto también fueron monitoreados por radio-telemetría para registrar posibles interacciones entre padres e hijo en sus ámbitos hogareños. A la edad aproximada de 21 meses, el ocelote subadulto comenzó a desplazar gradualmente su ámbito hogareño natal, estableciendo uno nuevo que fue ocupado hasta el final del estudio, en un área que había sido ocupada previamente por otro macho subadulto en dispersión. Se registraron solamente tres interacciones entre padres e hijo en los cuatro meses del desplazamiento. La aparente naturaleza pacífica de estos encuentros, junto con el lento abandono de una parte de su ámbito hogareño natal, sugieren que el subadulto no fue expulsado de su área natal por sus padres. El momento del desplazamiento, junto con el incremento en peso del subadulto (al peso propio de un adulto) cuatro meses después de haber establecido su nuevo territorio, sugiere que los desplazamientos del ámbito hogareño previos a la dispersión natal podrían actuar como una estrategia oportunista y de bajo riesgo para alcanzar el tamaño adulto, minimizando la competencia con padres y hermanos, en preparación para una dispersión final a un nuevo territorio para reproducirse.

Palabras clave: predispersión, subadulto, ocelote, Leopardus pardalis, desplazamiento del ámbito hogareño, radio-telemetría automatizada.

\section{REFERENCES}

Aliaga-Rossel, E., R.S. Moreno, R.W. Kays \& J. Giacalone. 2006. Ocelot (Leopardus pardalis) predation on agouti (Dasyprocta punctata). Biotropica 38: 691-694.

Bowler, D.E. \& T.G. Benton. 2005. Causes and consequences of animal dispersal strategies: relating individual behaviour to spatial dynamics. Biol. Rev. 80: 205-225.

Cochran, W.W. \& R.D. Lord. 1963. A radio tracking system for wild animals. J. Wildlife Manage 27: 9-24.

Croat, T.B. 1978. Flora of Barro Colorado Island. Stanford University, Stanford, California, USA.

Crawshaw, P.G. 1995. Comparative ecology of ocelot (Felis pardalis) and jaguar (Panthera onca) in a protected subtropical forest in Brazil and Argentina. Ph.D. Thesis, University of Florida, Gainesville, Florida, USA.

Dietrich, W.E., D.M. Windsor \& T. Dunne. 1996. Geology, climate, and hydrology of Barro Colorado Island, p. 21-46. In E.G. Leigh, A.S. Rand \& D.M. Windsor (eds.). The Ecology of a Tropical Forest. Smithsonian Institute, Washington, D.C., USA. 
Doncaster, C.P. \& D.W. Macdonald. 1997. Activity patterns and interactions of red foxes (Vulpes vulpes) in Oxford city. J. Zool., Lond. 241: 73-87.

Emmons, L.H. 1988. A field study of ocelots (Felis pardalis) in Peru. Rev. Ecol. Terre Vie 43: 133-157.

Fairbairn, D.J. 1978. Dispersal of deer mice, Peromyscus maniculatus -proximal causes and effects on fitness. Oecologia 32: 171-193.

Ferreras, P., M. Delibes, F. Palomares, J.M. Fedriani, J. Calzada \& E. Revilla. 2004. Proximate and ultimate causes of dispersal in the Iberian lynx (Lynx pardinus). Behav. Ecol. 15: 31-40.

Greenwood, P.J. 1980. Mating systems, philopatry, and dispersal in birds and mammals. Anim. Behav. 28: 1140-1162.

Haines, A.M., M.E. Tewes, L.L. Laack, W.E. Grant \& J. Young. 2005. Evaluating recovery strategies for an ocelot (Leopardus pardalis) population in the United States. Biol. Conserv. 126: 512-522.

Holden, C. 2006. Inching towards movement ecology. Science 313: 779-782.

Holdridge, L.R. 1967. Life zone ecology. Tropical Science Center, San José, Costa Rica.

Kays, R.W. 2006. My kingdom for a crown. Nat. Hist. 2006 (May): 72.

Kenward, R.E. 2001. A Manual for Wildlife Radio Tagging. Academic, London, UK.

Kreeger, T.J. 1999. Handbook of Wildlife Chemical Immobilization. Wildlife Pharmaceuticals, Fort Collins, Colorado, USA.

Laack, L.L. 1991. Ecology of the ocelot (Felis pardalis) in south Texas. M.S. Thesis, Texas A\&I University, Kingsville, Texas, USA.

Larkin, R.P., A. Raim \& R.H. Diehl. 1996. Performance of a Non-Rotating Direction-Finder for Automatic Radio Tracking. J. Field Ornithol. 67: 59-71.
Ludlow, M.E. \& M.E. Sunquist. 1987. Ecology and behavior of ocelots in Venezuela. Natl. Geogr. Res. 3: 447-461.

Macdonald, D.W. \& R.W. Kays. 2005. The Carnivora: the evolution, adaptive significance and conservation of their diversity, p. 1-67. In R. Nowak (ed.). Walkers Carnivores of the World. Johns Hopkins University, Baltimore, Maryland, USA.

Maehr, D.S., E.D. Land, D.B. Shindle, O.L. Bass \& T.S. Hoctor. 2002. Florida panther dispersal and conservation. Biol. Conserv. 106: 187-197.

Mares, R. 2005. Desplazamiento del ámbito hogareño previo a la dispersión natal del ocelote (Leopardus pardalis) en la isla de Barro Colorado. Tesis de Licenciatura, Universidad of Panamá, Panama.

Rogers, L.L. 1987. Effects of food supply and kinship on social behavior, movements, and population growth of black bears in northeastern Minnesota. Wildlife Monogr. 97: 1-72.

Roper, T.J., J.R. Ostler \& L. Conradt. 2003. The process of dispersal in badgers Meles meles. Mammal Rev. 33: $314-318$.

Smith, J.L.D. 1993. The role of dispersal in structuring the Chitwan tiger population. Behaviour 124: 165-195.

Sunquist, M. \& F. Sunquist. 2002. Wild Cats of the World. University of Chicago, Chicago, USA.

Sutherland, G.D., A.S. Harestad, K. Price \& K.P. Lertzman. 2000. Scaling of natal dispersal distances in terrestrial birds and mammals. Conserv. Ecol. 4: 16.

Tewes, M.E. 1986. Ecological and behavioral correlates of ocelot spatial patterns. Ph.D. Thesis, University of Idaho, Moscow, Idaho, USA.

Wright, S.J., M.E. Gompper \& B. Deleon. 1994. Are large predators keystone species in neotropical forests? The evidence from Barro Colorado Island. Oikos 71: 279-294. 